Hanne Støre Valeur (f. 1982) er assisterende medisinsk redaktør i Tidsskriftet.

Ingen oppgitte interessekonflikter.

Dette er en redigert versjon av debatten, publisert som rask respons på nett 20.8.2013. http://tidsskriftet.no/article/3037114/

\section{Vi trenger utdanningsstillinger i allmennmedisin}

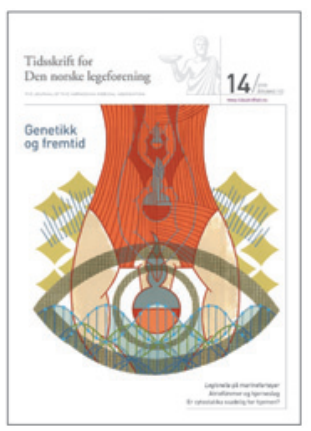

Hege Gjessing skriver i sin leder i Tidsskriftet nr. 14/2013 (1) at Legeforeningen har bedt Helse- og omsorgsdepartementet om å vurdere å opprette flere turnusstillinger.

Antall turnusstillinger er videreført fra et høyt nivå i den gamle ordningen. Jeg vil tro antall søkere vil falle når etterslepet fra 2012 er hentet inn. Det er ikke lenger slik at alle leger utdannet i EØS-landene kan melde seg på og få turnusplass. Turnustjenesten er nå starten på spesialisering etter norske regler. Sett fra kommunenes side er det ikke enkelt å opprette flere turnusplasser, ettersom antallet allerede er økt med $200 \%$ de siste 20 årene.

Derimot er det uten tvil behov for å opprette LIS-stillinger i allmennmedisin. Det er et betydelig etterslep i rekrutteringen til fastlegekorpset. Her må stat, kommuner og helseforetak samarbeide for å sikre at hele Norge skal ha mulighet til å få fastlege med et rimelig antall pasienter på sin liste.

\section{Oddmund Suhrke}

oddmund.suhrke@arendal.kommune.no

Oddmund Suhrke (f. 1953) er kommuneoverlege i Arendal kommune. Ingen oppgitte interessekonflikter.

\footnotetext{
Litteratur

1. Gjessing H. Det haster med en velfungerende turnustjeneste. Tidsskr Nor Legeforen 2013; 133: 1537
}

Dette er en redigert versjon av debatten, publisert som rask respons på nett 7.8.2013. http://tidsskriftet.no/article/3038130/

\section{H. Gjessing svarer:}

Det har lenge vært kø til turnuslegestillinger, og det er også behov for flere leger og legespesialister innenfor flere fag de nærmeste årene. Utdanning må planlegges i et langt tidsperspektiv. Det ønsker Legeforeningen å bidra til.

Vi trenger flere turnuslegestillinger som norske studenter og leger utdannet i utlandet kan søke på, og vi forventer en bedre dimensjonering mellom utdanningsplasser, turnuslegestillinger og det faktiske behovet for leger fremover.

Legeforeningen er videre opptatt av å få styrket legetjenestene i kommunene. Da samhandlingsreformen ble planlagt, ble det lagt til grunn at det er nødvendig med 2500 flere fastleger i kommunene. Dette var «glemt» da ordningen ble satt i verk i 2012. Men Legeforeningen fortsetter sitt arbeid med saken. Vi har nylig besluttet å sende ut et forslag til Opptrappingsplan for fastlegeordning på høring i organisasjonen. For å øke rekrutteringen til allmennpraksis må det tilrettelegges for utdanning av nye allmennleger med mål om at alle blir allmennlegespesialister.

Legeforeningen har derfor arbeidet for å øke antallet stillinger for fastleger i kommunene. Vi har hatt prosesser med departementet om dette spørsmålet - og i vår fikk vi en protokolltilførsel i normaltarifforhandlingen som slår fast at vi skal fortsette prosessen med å se på hvordan rekrutteringen til fastlegepraksiser kan styrkes.

\section{Hege Gjessing}

hege.gjessing@legeforeningen.no

Hege Gjessing (f. 1972) er president i Den norske legeforening. Ingen oppgitte interessekonflikter.

\section{RETTELSE}

Har pasienten virkelig hypertensjon?

Carl Ditlef Jacobsen

Tidsskr Nor Legeforen 2013; 133: 1687

I Tidsskriftet nr. 16/2013 under Brev til redaktøren har litteraturreferansen i Carl Ditlef Jacobsens innlegg falt ut. Her er den.

Litteratur

1. Jacobsen CD. Har pasienten virkelig hypertensjon? Tidsskr Nor Legeforen 2012; 132: 1946.

Vi beklager feilen. Den er rettet på nett. 